\title{
RENCANA LANSKAP WISATA EDUKASI KEBUN ANGGREK DI TAMAN KYAI LANGGENG KOTA MAGELANG
}

\section{Kasliyanti Islamiah}

Departemen Arsitektur Lanskap, Fakultas Pertanian, Institut Pertanian Bogor kasliyantiislamiah@gmail.com

\section{Dewi Rezalini Anwar}

Departemen Arsitektur Lanskap, Fakultas Pertanian, Institut Pertanian Bogor atelierlifescape@yahoo.com

\section{Vera D Damayanti}

Departemen Arsitektur Lanskap, Fakultas Pertanian, Institut Pertanian Bogor veradd@apps.ipb.ac.id

\begin{abstract}
Abstrak
Taman Kyai Langgeng (TKL) yang berlokasi di Kota Magelang dikenal sebagai salah satu tujuan wisata andalan di Propinsi Jawa Tengah. Jumlah pengunjung ke TKL sejak 2010 mengalami fluktuasi dan cenderung menurun sejak tahun 2015. TKL memiliki sebuah kebun anggrek yang berfungsi sebagai area propagasi dan diusulkan menjadi sebuah wahana wisata baru sebagai upaya meningkatkan jumlah pengunjung. Tujuan studi ini yaitu menghasilkan sebuah rencana lanskap untuk taman anggrek dengan pendekatan wisata edukatif. Proses perencanaan meliputi persiapan, pengumpulan data, analisis, sintesis, konsep, dan pembuatan rencana tapak. Analisis tapak menggunakan pendekatan deskriptif dan spasial terhadap komponen lanskap fisik dan bio-fisik serta elemen wisata. Wisata edukatif-rekreatif terkait anggrek menjadi konsep dasar perencanaan dimana rancangan fisik tapak menggunakan anatomi anggrek sebagai tema utama. Pengembangan rencana tapak berdasarkan rencana ruang yang terbagi atas ruang wisata utama dan pendukung wisata, dimana ruang wisata utama sebagai atraksi andalan terbagi atas ruang kreasi anggrek, taman tematik anggrek, hutan anggrek dan outlet anggrek. Dalam studi ini, kemiringan tapak dan prasyarat tumbuh anggrek menjadi faktor penting yang mempengaruhi penyusunan rencana tapak.
\end{abstract}

Kata-kata Kunci: Rencana Tapak, Taman Anggrek, Lanskap Wisata

\section{LANDSCAPE PLAN FOR ORCHID GARDEN EDU-TOURISM OF KYAI LANGGENG PARK IN MAGELANG CITY}

\begin{abstract}
Kyai Langgeng Park in Magelang City is known as one of the primary tourist destinations in Central Java Province. The visitor number of the park, however, had been fluctuated since 2010 and tended to decline since 2015. This park has an orchid garden, which initially functioned as a propagation area. This area was proposed to be improved into a touristic object as an attempt to attract more visitors. The main objective of this study, therefore, is to produce a site plan for the
\end{abstract}


garden by considering its physical landscape and educational tourism elements. The planning process included preparation, data inventory, analysis, synthesis, concept, and site planning. The site analysis applied a descriptive and spatial analysis of the biophysical landscape and tourism components. By assigning the educative and recreative tourism as the fundamental concept for the site development with orchid as the core theme, the site plan was arranged based on the spatial plan of main touristic and supporting zones. The main touristic zone as the major attraction is divided into three areas: orchid-based creativity, orchid theme garden, orchid jungle, and orchid outlet. It is apparent that the site's slope and the prerequisite condition to support the optimum orchid's growth have become significant factors that influenced the site plan considerably.

\section{Keywords: Site Plan, Orchid Garden, Tourism Landscape}

\section{Pendahuluan}

Pariwisata merupakan komoditas yang berperan penting dalam bidang sosial dan ekonomi bagi masyarakat. Berwisata merupakan kegiatan perjalanan baik dengan tujuan rekreatif maupun nonrekreatif. Dalam konteks ini, kepuasan dan kenyamanan pengunjung berwisata merupakan faktor penting bagi para pelakunya (Gunn, 1997). Oleh karenanya, secara sosial berwisata dapat bermanfaat sebagai media berelaksasi dan menambah pengalaman. Industri pariwisata sendiri berkontribusi besar terhadap pembangunan perekonomian lokal dan nasional sebagai sumber pendapatan, investasi, dan penyedia lapangan kerja. Sektor ini hingga 2018 menempati ranking keempat penyumbang devisa negara (Media Indonesia, 2018). Saat ini banyak daerah di Indonesia giat membenahi kepariwisataan lokal, termasuk di Kota Magelang, Jawa Tengah.

Taman Kyai Langgeng (TKL) merupakan salah satu tujuan wisata andalan Kota Magelang yang dimiliki oleh pemerintah kota. TKL pada dasarnya berupa kawasan wisata dengan beragam wahana didalamnya. Kemunculan beragam obyek wisata di Kota Magelang dan sekitarnya ikut berpengaruh terhadap jumlah pengunjung TKL. Hal ini terlihat dari data yang tercatat sejak 2015 hingga 2018 bahwa pengunjung TKL mengalami penurunan signifikan (BPS Kota Magelang, 2019). Salah satu upaya meningkatkan daya tarik TKL yaitu dengan mengusulkan kebun anggrek yang masih sub-optimal penggunaannya sementara keberadaannya potensial menjadi sebuah wahana baru dalam TKL. Dengan adanya kebutuhan masyarakat perkotaan terhadap ruang luar diantaranya terhadap alam dan interaksi sosial (Matsuoka dan Kaplan, 2008), diharapkan kebun anggrek TKL nantinya mampu memenuhi kebutuhan tersebut melalui berbagai aktivitas wisata yang akan dikembangkan di dalamnya.

Untuk menjadikan kebun ini sebagai obyek wisata diperlukan penataan tapak yang menunjang fungsi wisata. Pengembangan tapak perlu diarahkan untuk menawarkan pengalaman wisata yang edukatif. Banyak hal yang harus ditata jika kebun ini akan dikembangkan sebagai obyek wisata. Komponen yang menunjang fungsi wisata seperti atraksi, pelayanan, transportasi, informasi, dan promosi harus direncanakan dengan baik untuk menunjang keberhasilannya (Gunn, 1997). Untuk itu tujuan utama studi yaitu menyusun rencana tapak Kebun Angrek TKL sebagai obyek wisata bernilai edukasi, melalui identifikasi dan analisis kondisi biofisik tapak dan potensi wisata kebun anggrek. Rencana tapak dibuat dengan mempertimbangkan kondisi biofisik agar berkelanjutan, serta diharapkan mampu menunjang karakter tapak sebagai sebuah kebun anggrek.

\section{Lanskap dan Perencanaan Lanskap}

Lanskap adalah sebuah bentang alam dengan karakteristik tertentu dengan nilai khas yang dapat berupa keseluruhan tapak maupun hanya berupa pemandangan yang dapat dinikmati oleh seluruh indera manusia. Karakter suatu lanskap dipengaruhi oleh elemen-elemen lanskap 
pembentuknya, baik yang bersifat alami maupun buatan. Elemen lanskap alami ada yang bersifat mayor-dimana sulit untuk dirubah, misalnya unsur iklim dan landform makro seperti gunung dan sungai; dan besifat minor, yaitu masih dapat dimodifikasi, misalnya bukit dan vegetasi (Simonds dan Starke, 2006).

Perencanaan lanskap merupakan salah satu kegiatan utama di bidang arsitektur lanskap yang melibatkan proses pemikiran ide, gagasan, atau konsep ke arah bentuk bentang alam yang nyata. Kegiatan ini berbasis lahan (land base planning) dan melibatkan pemecahan masalah serta merupakan proses pengambilan keputusan jangka panjang guna mendapatkan suatu model lanskap yang fungsional, estetik dan lestari yang mendukung berbagai kebutuhan dan keinginan manusia agar nyaman dan sejahtera (Nurisjah dan Pramukanto, 2007). Kegiatan ini tak lepas dari penciptaan karakter lanskap sesuai dengan fungsi yang direncanakan. Karakter lanskap terbentuk dari perpaduan elemen ruang, material baik alami maupun buatan, bentuk dan proses terkait aktivitas dan proses alami/non-alami dalam ruang (Spirn, 1998).

Dalam merencana, elemen pengguna merupakan aspek yang perlu dipertimbangkan, baik dari sisi preferensi maupun dampak aktivitasnya. Preferensi pengguna terhadap kualitas visual area rekreasi perkotaan dipengaruhi diantaranya oleh keberadaan elemen badan air, lebar jalur pedestrian, fungsi area, warna dan komposisi tanaman serta keragaman jenis tanaman (Polat dan Akay, 2015). Dalam hal dampak pengguna, pengembangan aktivitas dalam perencanaan lanskap harus mempertimbangkan tempat yang sesuai dengan daya dukung lahan serta memperhatikan kondisi masyarakat sekitar agar nantinya implementasi rencana berkelanjutan (Simonds dan Starke 2006).

\section{Pengembangan lanskap wisata}

Wisata (tour) adalah perpindahan orang untuk sementara dalam jangka waktu tertentu ke tujuan-tujuan di luar tempat dimana mereka biasa tinggal dan bekerja. Wisatawan pergi ke suatu obyek wisata karena didasari motivasi yang bersifat rekreatif atau non-rekreatif (Gunn, 1997). Perjalanan ke suatu tempat untuk belajar sesuatu merupakan salah satu motivasi non-rekreatif dalam wisata yang melatarbelakangi wisata edukasi. Ritchie et. al. (2003) menyatakan wisata edukasi merupakan suatu perjalanan yang melibatkan kegiatan edukatif, baik yang dilakasanakan secara formal maupun informal. Aspek pembelajaran dalam wisata memiliki cakupan mulai dari belajar terhadap hal-hal menarik secara umum ketika sedang berwisata hingga berwisata dengan tujuan khusus untuk belajar hal tertentu (CTC, 2004). Wisata edukasi dapat dikembangkan berbasis alam dan budaya (Ritchie et.al, 2003). Bidang pertanian secara luas, termasuk didalamnya florikultura, dikategorikan sebagai suatu bentuk budaya bercocok tanam; oleh karenanya kegiatan ini dapat dikembangkan untuk wisata edukasi berbasis budaya.

Pariwisata pada dasarnya terkait dengan pengalaman pengunjung. Pengalaman berwisata dapat muncul melalui berbagai dimensi seperti rasa senang, interaksi sosial, hal baru, nyaman, aman, dan tantangan (Otto dan Ritchie, 1996). Untuk memberikan pengalaman wisata, maka perlu pengembangan kawasan wisata yang dapat dilakukan dengan pendekatan supply dan demand. Dalam penelitiannya, Wijayanti et al. (2017) menyimpulkan bahwa sisi supply menciptakan pengalaman berwisata yang lebih besar dalam memberikan pengalaman berwisata bagi pengunjung. Gunn (1997) mengemukakan perencanaan kawasan wisata merupakan proses pengintegrasian komponenkomponen wisata dari sisi supply yang meliputi daya tarik, pelayanan, transportasi, informasi, dan promosi. Daya tarik wisata merupakan salah satu komponen penting dalam pariwisata yang berfungsi untuk menarik minat seseorang berwisata dan memberikan kepuasan kepada pengunjung (Gunn, 1997).

Dalam wisata edukasi terdapat dua komponen utama dari sisi supply yang perlu direncanakan yaitu pertama, produk wisata utama yang meliputi daya tarik dan event, spesialis terkait sumberdaya yang akan diajarkan, perencana tour afinitas, dan operator. Kedua yaitu elemen sekunder seperti transportasi, pelayanan, dan pemasaran (CTC, 2004). Produk wisata tidak hanya fokus pada 
pengembangan bentukan fisik daya tarik wisata namun juga memperhatikan elemen pendukung yang intangible seperti layanan, keramahan, serta aspek terkait ruang dan aktivitas yaitu keterlibatan pengunjung dan keleluasaannya dalam memilih kegiatan (Xu, 2010).

\section{Anggrek sebagai elemen lanskap}

Anggrek merupakan salah satu tumbuhan berbunga yang keragamannya tinggi dan tersebar di dunia. Dari sekitar 20.000 spesies anggrek, 6.000 diantaranya berada di hutan Indonesia. Berdasarkan tempat tumbuhnya, anggrek dibagi menjadi: (1) anggrek terestrial atau tumbuh di permukaan tanah dan membutuhkan cahaya matahari langsung; (2) anggrek epifit yang tumbuh dan hidup menumpang pada batang atau cabang pohon tetapi tidak merugikan tanaman yang ditumpanginya dimana terdapat jenis yang membutuhkan sinar matahari penuh hingga di bawah naungan; (3) anggrek litofit yaitu anggrek yang tumbuh dan hidup pada batu-batuan tepi pantai yang tahan cahaya matahari langsung dan terpaan angin; (4) anggrek saprofit yang tumbuh dan hidup pada humus atau kompos serta membutuhkan naungan. Agar pertumbuhan anggrek optimal maka persyaratan dan kebutuhan hidupnya harus terpenuhi yang mencakup ketinggian tempat, suhu, kelembapan udara, sirkulasi udara, kebutuhan cahaya, serta kebutuhan air (Darmono, 2004; Anggara, 2008; Yulia dan Yanti, 2010).

\section{Metode}

\section{Lokasi}

Studi ini dilakukan di kebun anggrek dalam kawasan Taman Kyai Langgeng yang berlokasi di Jalan Cempaka No 6, Kelurahan Kemirirejo, Kecamatan Magelang Tengah, Kota Magelang, Jawa Tengah (Gambar 1).

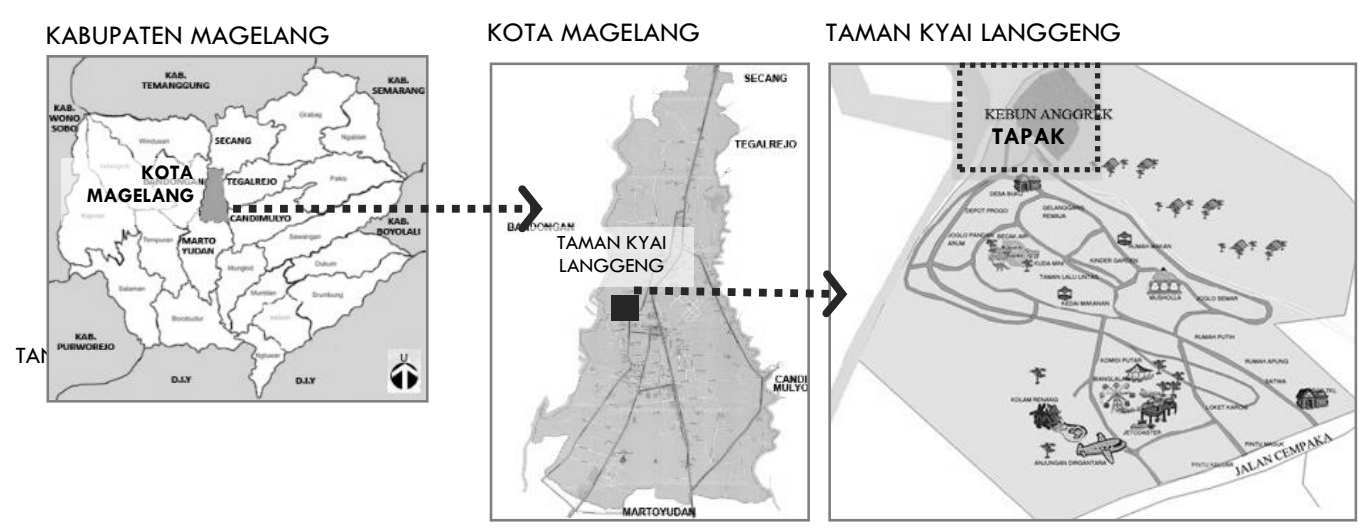

Gambar 1. Lokasi Studi

Sumber: Googlemap Dan Brosur TKL, 2013

\section{Tahapan dan Metode}

Perencanaan tapak dilakukan melalui tahapan pengumpulan data, analisis, sintesis, penyusunan konsep dan rencana tapak. Rencana tapak sebagai hasil akhir studi, beserta produk gafis lainnya dibuat dengan menggunakan aplikasi AutoCAD dan Photoshop.

Data yang dikumpulkan meliputi data primer dan sekunder, terdiri dari aspek biofisik tapak (topografi, kemiringan, iklim, tanah, vegetasi, aksesibilitas dan sirkulasi, visual) dan aspek wisata (atraksi/objek wisata, saran-prasarana, pengunjung, pengelola). Data primer diperoleh dengan metode survei melalui pengamatan, dokumentasi dan pengukuran di tapak. Dilakukan pula indepthinterview dengan dua orang pengelola tapak, dan wawancara terstruktur menggunakan kuisioner terhadap 30 pengunjung dengan metode random sampling untuk mengetahui karakter pengunjung dan 
responnya terdahap kebun anggrek. Pengumpulan data sekunder dilakukan dengan studi literatur berbagai publikasi dan laporan terkait Kota Magelang dan TKL.

Metode analisis yang diterapkan yaitu secara spasial, kuantitatif dan deskriptif. Analisis spasial dilakukan terhadap aspek topografi-kemiringan dan vegetasi terkait run-off, dengan menggunakan skor dan pembobotan. Dengan mempertimbangkan bagian tapak yang berlereng, kedua aspek tersebut menjadi faktor penentu agar pengembangan tapak sesuai dengan daya dukungnya sehingga berkelanjutan. Aspek kemiringan tapak dianalisis dengan paramater kesesuaiannya untuk pengembangan kegiatan yang mengacu pada standar yang dikembangkan oleh Booth (1983), dimana kemiringan tapak $0-5 \%$ sesuai, $5-15 \%$ cukup sesuai, dan $>15 \%$ tidak sesuai untuk kegiatan. Selain itu, kemiringan tapak juga dianalisis kerentanannya terhadap parameter bahaya erosi (run-off) dengan menggunakan batas kemiringan yang dikemukakan oleh Darmawijaya (1990), dimana kemiringan 0-3\% tidak ada erosi, 3-15\% erosi tidak berbahaya, dan $>15 \%$ erosi berbahaya. Sementara itu aspek vegetasi dianalisis dengan parameter fungsi ekologisnya terkait penghambat erosi, dengan kriteria ada-tidaknya vegetasi dan jenisnya (pohon, semak, penutup tanah).

Jenis tanah, elemen hidrologi, iklim dan vegetasi dalam konteks budidaya anggrek dianalisa secara deskriptif. Analisis secara deskriptif juga diaplikasikan pada analisi aspek aksesibilitas dan sirkulasi, visual, obyek-atraksi wisata, sarana-prasarana dan pengelola. Sedangkan hasil wawancara pengunjung dihitung prosentasenya. Hasil analisis spasial kelerengan untuk pengembangan aktivitas, bahaya erosi dan potensi vegetasi kemudian dioverlay untuk mendapatkan peta komposit kesesuaian pengembangan tapak dengan menggunakan pembobotan 0,35:0,35:0,30.

Selanjutnya disusun konsep dasar perencanaan tapak yang kemudian dijabarkan menjadi konsep pengembangan ruang, sirkulasi, vegetasi, aktivitas, dan fasilitas. Peta komposit hasil analisis menjadi dasar pembagian zona kesesuaian aktivitas wisata berdasarkan tingkat intensitasnya. Hasil analisis deskriptif terhadap aspek biofisik lainnya dan konsep menjadi bahan pertimbangan dalam membagi ruang pada peta komposit untuk mendapatkan rencana blok/blockplan. Detail blockplan ini dituangkan kedalam site plan sebagai output utama, yang menampilkan elemen tapak yang diperkuat dengan tema dan bentukan anggrek.

\section{Hasil Dan Pembahasan}

\section{Kondisi Taman Kyai Langgeng}

\section{A. Lokasi dan aksesibilitas}

TKL memiliki luasan 27,05 Ha dengan batas utara TKL berupa perumahan penduduk, sebelah selatannya adalah Jalan Cempaka serta akomodasi wisata, sebelah timur Jalan Cempaka, dan sebelah barat Kali Progo. Kawasan ini berlokasi di tengah kota sehingga mudah diakses dari arah Yogyakarta, Semarang, dan Purworejo, dimana ketiga kota tersebut merupakan akses utama menuju Kota Magelang dari kota-kota yang berbatasan dengannya.

\section{B. Aspek wisata}

Kawasan TKL menawarkan berbagai obyek dan atraksi wisata yang sebagian berbayar dan sebagian gratis. Berbagai daya tarik didalamnya terdiri dari taman hiburan (amusement park) dengan berbagai wahana permainan seperti jet coaster, bianglala dan sebagainya; taman tematik seperti taman lalu lintas, mini zoo, koleksi tanaman langka, taman buku, waterpark, camping ground, dan kebun anggrek. Terdapat berbagai fasilitas penunjang wisata seperti gerbang, area parkir, kios cinderamata, loket tiket, pos jaga, papan informasi, jalur sirkulasi, toilet, kantin, tempat duduk-duduk, dan mushola.

Potensi pengunjung TKL dapat dilihat dari jumlah pengunjung dan karakternya. Berdasarkan data wisatawan TKL 2010-2018, jumlah pengunjung berfluktuasi dan cenderung menurun sejak 2015, dimana selama 2015 mencapai 1.139.454 orang dan terus menurun hingga 2018 terdapat 608.380 (BPS Kota Magelang, 2018; 2019). Karakter pengunjung TKL dikaji melalui 
penyebaran kuisioner ke responden pengunjung. Responden kelompok usia 15-59 tahun umumnya berkunjung dalam kelompok (87\%) dan sisanya bersama keluarga (13\%). Responden berkunjung karena pemandangan TKL sebagai daya tarik utama (73\%), menikmati wahana permainan (17\%) dan koleksi tanaman langka (10\%). Respon pengunjung terhadap wacana pengembangan kebun anggrek cukup baik dimana $80 \%$ menyatakan keinginannya berkunjung, $17 \%$ respon ragu-ragu, dan 3\% tidak bersedia berkunjung. Berdasarkan respon tersebut terlihat bahwa kebun anggrek sangat potensial menjadi daya tarik wisata TKL.

\section{Data dan Analisis}

\section{A. Kondisi awal Kebun Anggrek}

Kebun Anggrek seluas 8.459,5 $\mathrm{m}^{2}$ ini awalnya difungsikan sebagai areal pembibitan anggrek. Didalamnya terdapat rumah pengelola dan fasilitas pembibitan rumah kaca. Aktivitas di dalam kebun anggrek berupa pembudidayaan anggrek sampai tahap pembesaran serta pemeliharaan harian dan belum ada aktivitas wisata. Batas-batas dan kondisi eksisting tapak disajikan pada Gambar 2. Ketinggian tapak sekitar 380 mdpl, dengan topografi sebagian besar $(60 \%)$ berlereng terutama di bagian selatan, dimana pada area tersebut didominasi oleh pepohonan. Sementara itu bagian utara cenderung datar dan terdapat bangunan tempat perbanyakan anggrek.

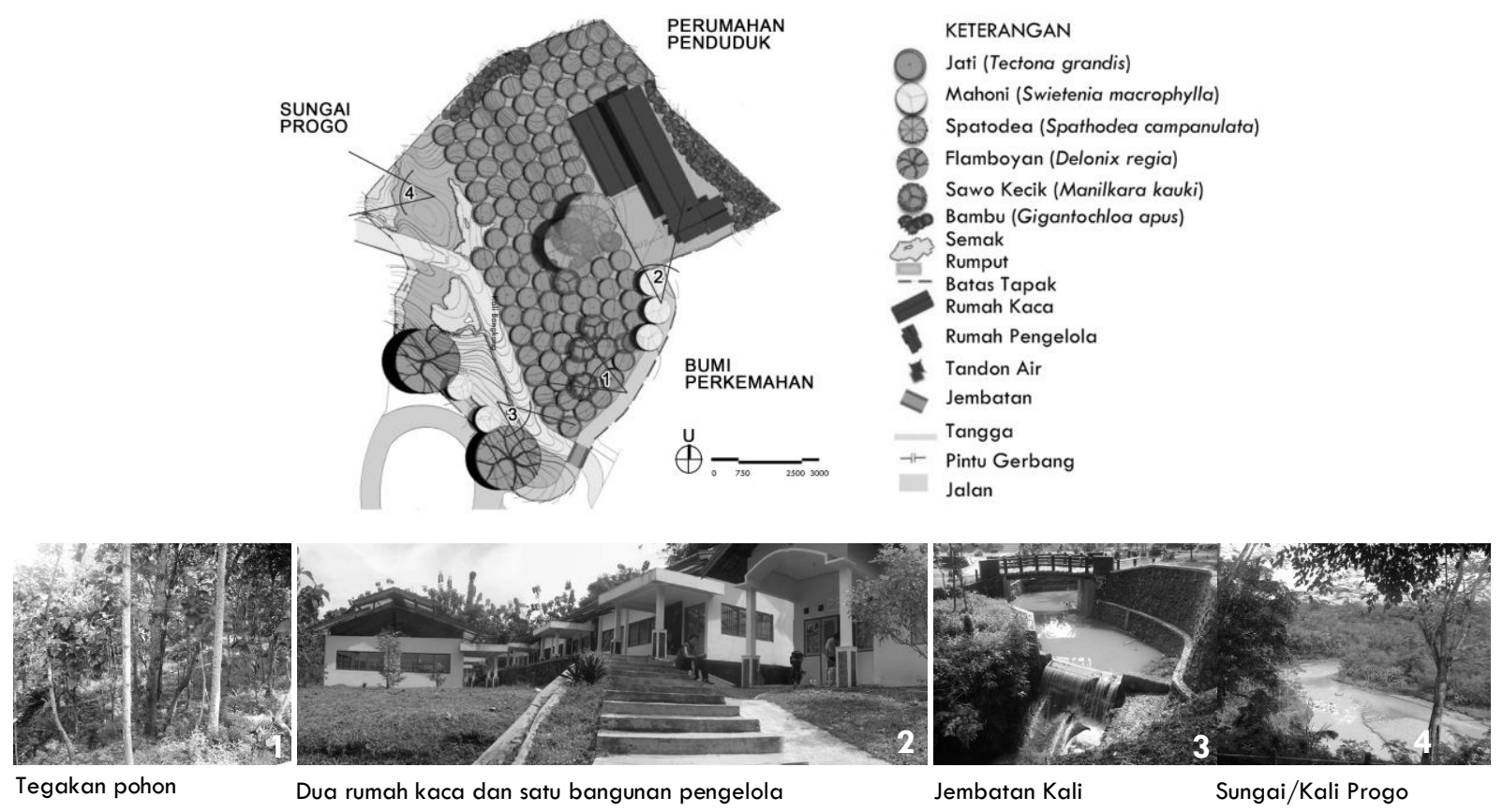

Gambar 2. Kondisi Eksisting Kebun Anggrek

Sumber: Hasil Observasi Tapak, 2013

\section{B. Aspek biofisik dan bio-fisik}

Analisis elemen topografi dilakukan berdasarkan parameter kemampuan tapak untuk mendukung pengembangan aktivitas wisata dilihat dari kelerengan dan potensi erosi di tapak. Peta spasial berdasarkan kedua parameter tersebut kemudian di-overlay, dan untuk mendapatkan peta komposit, masing-masing dengan bobot 0,5. Peta ini memberi gambaran spasial terkait kesesuaian tapak untuk pengembangan wisata yang mempertimbangkan kelestarian sumber daya lahan (Gambar 3). 
Pada tapak terdapat kelerengan $>15 \%$ yang kurang sesuai untuk aktivitas dan berpotensi erosi bahaya. Namun demikian, kelerengan 5-15\% mendominasi tapak, dimana menurut Booth (1983) kemiringan tersebut landai sampai berbukit yang sesuai untuk berbagai tipe penggunaan lahan dan aktivitas yang bersifat terbatas. Dengan kelerengan tersebut, kecepatan run-off umumnya lambat sampai sedang. Mengacu pada Darmawijaya (1990), aliran permukaan (runoff) tersebut memiliki tingkat erosi yang tidak berbahaya. Berdasarkan hasil overlay (Gambar 3), tapak didominasi area yang cukup sesuai untuk aktivitas wisata dengan potensi erosi yang tidak berbahaya asalkan kondisi vegetasi eksisting tidak mengalami banyak perubahan.

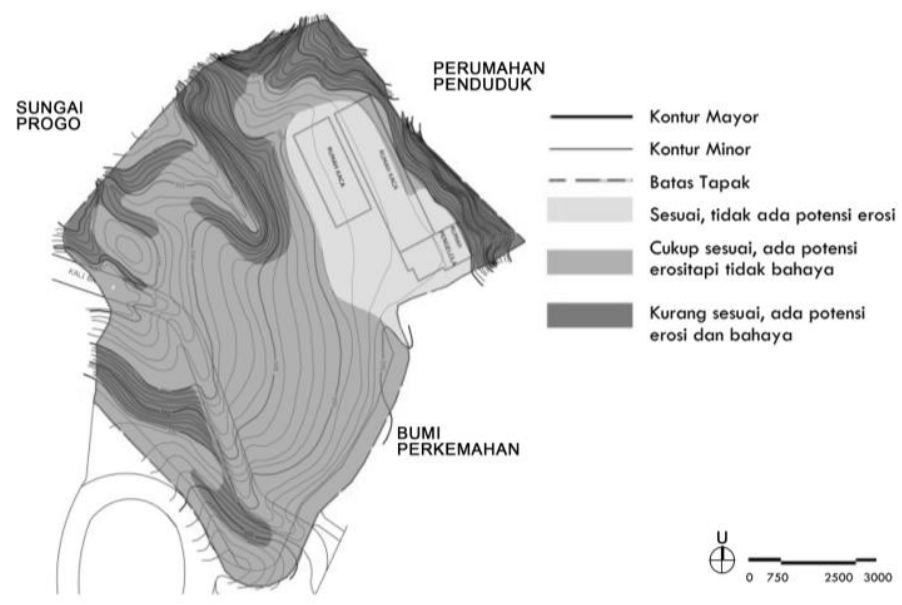

Gambar 3. Peta Kesesuaian Tapak Untuk Aktivitas Wisata Sumber: Hasil Analisis, 2013

Vegetasi di tapak terdiri dari vegetasi indoor dalam rumah kaca dan yang ada di sekitarnya. Vegetasi dalam rumah kaca merupakan komoditas utama kebun yaitu bibit anggrek. Vegetasi yang ada di sekitar rumah kaca terdiri atas pohon jati (Tectona grandis), spatodea (Spathodea campanulata), mahoni (Swietenia macrophylla), flamboyan (Delonix Regia), bambu (Gigantochloa apus), serta paku-pakuan pada dinding tebing Kali Bangkong. Pohon Jati dominan di tapak dan potensial sebagai pohon inang anggrek epifit. Kulit batangnya yang licin dapat disiasati dengan menempeli media seperti serabut kelapa atau potongan pakis di batang pohon sehingga dapat menahan air (Iswanto, 2002).

Analisis spasial aspek vegetasi dilakukan berdasarkan adanya vegetasi untuk menjaga sumber daya lahan untuk mengikat tanah dan meningkatkan infiltrasi air. Vegetasi yang memiliki fungsi ekologis seperti pohon jati, bambu, dan pohon-pohon lainnya serta paku-pakuan pada dinding badan Kali Bangkong dinilai sangat sesuai untuk menjaga sumber daya lahan. Sementara itu penutup tanah seperti rumput dan semak yang diatasnya tidak ada tegakan pohon kemampuannya dalam mengikat tanah dan air dianggap kurang potensial. Hasil analisis spasial vegetasi disajikan pada Gambar 4. 


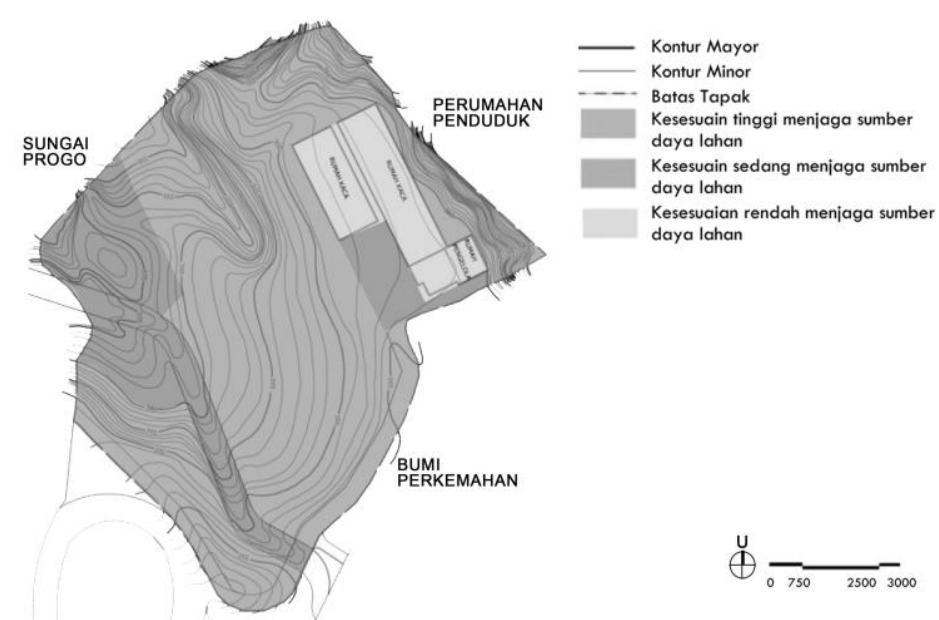

Gambar 4. Peta Analisis Vegetasi

Sumber: Hasil Analisis, 2013

Kondisi jenis tanah di tapak yaitu alluvial yang merupakan hasil pelapukan batuan yang cukup intensif dari sedimentasi alluvial di sepanjang Kali Progo dan Kali Elo yang berasal dari Gunung Merapi. Sedimen ini masih muda dan kaya akan unsur hara sehingga subur. Sedangkan berdasarkan sifat fisiknya, jenis tanah ini rentan longsor terutama pada area berlereng. Oleh karenanya dalam pengadaan fasilitas di tapak dibutuhkan perlakuan khusus untuk menjaga kestabilannya, misalnya melalui penanaman vegetasi pelindung.

Kota Magelang memiliki suhu dengan kisaran $20-32^{\circ} \mathrm{C}$ dan kelembaban rata-rata $88,8 \%$ (Pemkot Magelang, 2020). Berdasarkan penghitungan THI, tapak tergolong nyaman. Kenyamanan ini tercipta dengan banyaknya pepohonan yang membantu mereduksi intensitas panas matahari. Oleh karenanya keberadaan pohon-pohon ini perlu dipertahankan untuk menjaga kenyamanan tapak.

Kebun Anggrek dapat diakses dengan mudah walaupun letaknya berada di sisi belakang atau sebelah barat laut TKL. Tapak terpisah dari kawasan TKL oleh Kali Bangkong, dan dihubungkan oleh sebuah jembatan. Jalur sirkulasi eksisting dalam tapak terdiri dari jalur untuk menunjang kegiatan perbanyakan anggrek berupa perkerasan yang terpelihara; dan jalan setapak di sela-sela pepohonan di selatan tapak yang cenderung tidak terpelihara. Jalan setapak terhubung dengan Kali Progo dan dapat membahayakan pengunjung bila debit sungai sedang meningkat, sehingga diperlukan pembatas antara tapak dengan sungai sebagai pengaman.

Suplai air bersih di tapak bersumber dari air tanah. Dengan kondisi tapak yang sebagian berlereng, maka aspek hidrologis aliran permukaan perlu diperhatikan. Aliran permukaan merupakan bagian dari siklus hidrologi, berpengaruh terhadap ketersediaan air tanah karena jika lajunya tinggi, maka air tidak tersimpan dalam tanah, demikian pula sebaliknya. Untuk mempertahankan ketersediaannya, maka siklus hidrologis harus dijaga. Oleh karenanya, areaarea yang berpotensi memiliki tingkat run-off yang tinggi perlu dilindungi untuk menekan laju aliran permukaan, misalnya melalui penanaman vegetasi yang dapat menekan run-off dan pembuatan kolam resapan.

Secara umum kondisi visual tapak didominasi oleh pohon jati yang tumbuh menyebar di sisi selatan rumah kaca. Tegakan vegetasi ini mengakibatkan pandangan dari luar ke rumah kaca maupun sebaliknya terhalang. Padahal Kebun Anggrek dikelilingi oleh area-area yang 
memiliki pemandangan menarik (good views). Sementara itu di dalam tapak kondisi rumah kaca kurang terpelihara sehingga menimbulkan pemandangan kurang baik (bad views), ditambah lagi dengan rumput tumbuh liar serta pepohonan dan semak-semak yang tak tertata.

\section{Aspek wisata}

Hingga saat ini belum terdapat daya tarik yang menarik wisatawan berkunjung ke tapak. Kegiatan pembibitan dan pembesaran anggrek sepertinya tidak menarik pengunjung, yang bisa jadi disebabkan tidak dipromosikannya kebun ke pengunjung atau kegiatan dalam kebun tidak menarik.

Untuk menciptakan daya tarik wisata pada tapak dapat dilakukan melalui beberapa cara. Pertama, aktivitas budidaya anggrek dikembangkan sebagai atraksi wisata bermuatan edukasi. Kedua, komoditas anggrek yang sudah berbunga berpotensi sebagai obyek utama dalam kebun dengan spesies, bentuk, dan corak yang beragam dapat dirancang penataannya untuk menarik pengunjung. Kegiatan budidaya anggrek yang saat ini hanya sebatas pembibitan dan pembesaran dapat ditingkatkan aktivitasnya sampai tahap pembungaan. Iklim tapak yang tidak mendukung pembungaan dapat diatur melalui rekayasa suhu dan kelembaban yang sesuai untuk pembungaan anggrek dalam rumah kaca. Daya tarik lain untuk menarik pengunjung yaitu dengan mengadakan berbagai event dengan anggrek sebagai fokusnya. Event tersebut dapat diselenggarakan secara periodik maupun insidental, misalnya workshop budidaya anggrek dan festival anggrek yang menampilkan berbagai perlombaan seperti menggambar dan fotografi dengan anggrek sebagai obyek utamanya. Kedua cara tersebut juga merupakan upaya perbaikan kualitas visual lanskap taman anggrek agar sesuai dengan preferensi pengunjung (Polat dan Akay, 2015).

Tidak banyak terdapat fasilitas penunjang di tapak saat ini. Hanya terdapat dua buah rumah kaca dan satu bangunan pengelola di sebelah utara sebagai struktur pengisi tapak. Di rumah pengelola tidak terlihat aktivitas karena hanya difungsikan untuk menyimpan barang. Pengelola tapak terdiri dari para pihak yang terlibat dalam pengelolaan kebun anggrek, meliputi Perusahaan Daerah Obyek Wisata (PDOW) TKL, Dinas Pertanian, dan Asosiasi Tanaman Hias Kota Magelang. Kebun anggrek merupakan bagian dari PDOW TKL di bawah Dinas Pertanian Kota Magelang. Asosiasi berperan selaku penyedia bibit anggrek bagi kebun. Kegiatan pengelola berupa budidaya perbanyakan vegetatif anggrek, pemasaran anggrek serta pemeliharaan tapak. Dengan demikian hingga saat ini belum terdapat kegiatan pengelolaan terstruktur terkait dengan aktivitas wisata. Tak heran meskipun TKL padat pengunjung, terutama di akhir pekan dan hari libur, tidak terdapat kunjungan ke kebun anggrek.

\section{Hasil Analisis}

Berdasarkan peta komposit hasil overlay aspek biofisik kelerengan dan vegetasi (Gambar 5), didapatkan area dengan 3 tingkat intensitas kesesuaian aktivitas wisata di tapak yaitu:

a. Area dengan intensitas tinggi, meliputi sebelah utara tapak dengan relief permukaan cenderung datar (0-5\%) sehingga dapat dikembangkan aktivitas intensif. Kondisi area yang datar memungkinkan konstruksi bangunan masif seperti rumah kaca, ruang informasi, dan fasilitas wisata lainnya. Bibit anggrek yang dibudidayakan pada area ini memiliki nilai ekonomi sehingga dipertahankan dengan memberikan fasilitas untuk meningkatkan produksinya.

b. Area dengan intensitas sedang, didominasi kemiringan landai hingga bergelombang (5-15\%), terutama di sebelah selatan tapak. Aktivitas yang dapat dilakukan didalamnya terbatas dan cenderung pasif atau semiintensif dengan konstruksi fasilitas wisata memperhatikan arah kemiringan lahan atau ditempatkan sejajar dengan kontur. Run-off lambat-sedang di area ini dapat ditekan dengan sumur resapan atau kolam yang sekaligus sebagai salah satu sumber air 
pemeliharaan kebun dan sebagai feature elemen tapak yang menarik pengunjung. Pohon jati yang dominan di area ini beberapa dipilih untuk dipertahankan.

c. Area dengan intensitas rendah, kemiringan area ini cenderung curam $(>15 \%)$, berlokasi di beberapa titik di tapak. Kemiringan tersebut menjadi faktor pembatas sehingga aktivitas yang diperkenankan sangat terbatas dan nonintensif. Konstruksi fisik sebisa mungkin dihindari karena area ini memiliki potensi erosi yang besar. Oleh karenanya, bentuk pengembangan area ini berupa tindakan konservasi. Vegetasi yang telah ada dipertahankan dan diperkaya untuk menunjang upaya konservasi tersebut.

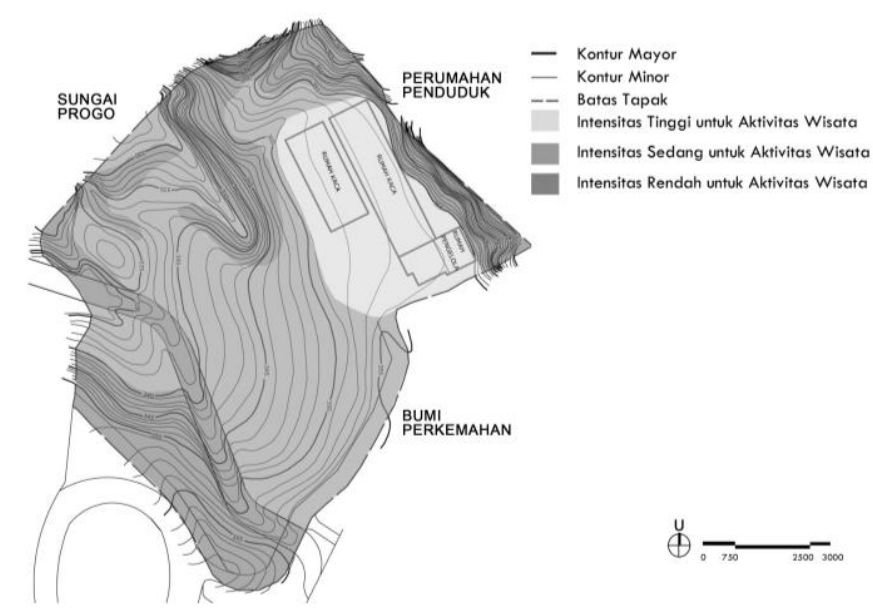

Gambar 5. Peta Komposit

Sumber: Hasil Analisis, 2013

\section{Konsep perencanaan}

Konsep dasar perencanan yaitu anggrek sebagai sumber daya tarik wisata edukatif dan rekreatif, dengan menonjolkan karakter anggrek sebagai elemen tapak dan memperhatikan keberlanjutan fisik tapak. Pengembangan aspek edukatif bertujuan memperkenalkan budidaya dan pengetahuan tentang berbagai jenis anggrek kepada para pengunjung. Aspek rekreatif bertujuan agar pengunjung mendapatkan pengalaman yang menarik dan menyenangkan melalui sajian keindahan visual koleksi anggrek atau terlibat dalam kegiatan/event (participatory). Dengan demikian, kebun anggrek tidak hanya sebagai kebun pembibitan namun juga sebagai obyek wisata yang edukatif dan rekreatif.

Pengembangan obyek wisata kebun anggrek harus mengakomodir kepentingan produksi dan pengunjung, dan tetap memperhatikan daya dukung tapak agar berkelanjutan. Menjaga kelestarian sumber daya tapak merupakan salah satu aspek penting yang menentukan keberhasilan suatu rencana lanskap (Simonds dan Starke, 2006; Nurisjah dan Pramukanto, 2007). Untuk itu fungsi yang akan dikembangkan mencakup: (1) fungsi produksi berkaitan dengan keberlanjutan produksi anggrek sebagai komoditas utama pada tapak; (2) fungsi wisata untuk memenuhi kebutuhan pengunjung yang dituangkan dalam obyek dan atraksi wisata serta fasilitas penunjangnya dalam tapak; dan (3) fungsi penyangga untuk konservasi sumber daya fisik lahan.

Konsep dasar kemudian dikembangkan menjadi konsep ruang, sirkulasi, vegetasi, aktivitas serta fasilitas wisata. Pada konsep ruang, stuktur ruang yang terbentuk berdasarkan fungsi, yaitu ruang produksi, ruang wisata (pendukung dan utama), dan ruang penyangga baik sebagai pelindung maupun buffer. Ruang-ruang tersebut dihubungkan melalui jalur sirkulasi, yang terbagi atas sirkulasi produksi dan sirkulasi wisata. Pengembangan pola sirkulasi di dalam ruang wisata mengadopsi bentukan bunga anggrek yang diaplikasikan di tapak khususnya pada ruang wisata anggrek. 
Pengaplikasian bentukan bunga anggrek pada konsep sirkulasi ditujukan untuk memunculkan karakter anggrek pada elemen tapak (Gambar 6).

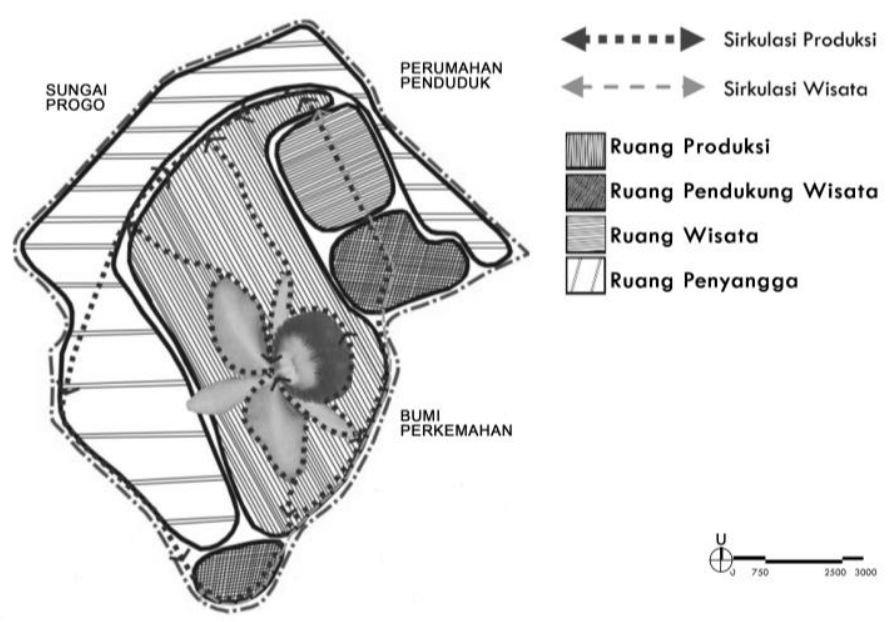

Gambar 6. Diagram Konsep Ruang Dan Sirkulasi Sumber: Hasil Penyusunan Konsep, 2013

Secara umum konsep vegetasi terbagi menjadi dua yaitu vegetasi utama dan pendukung. Vegetasi utama yaitu anggrek yang menjadi obyek utama di tapak. Vegetasi pendukung berupa vegetasi yang mendukung keberadaan anggrek, menjaga kelestarian tapak, maupun penambah estetika tapak. Selanjutnya konsep aktivitas wisata merupakan penjabaran berbagai aktivitas yang direncanakan berdasarkan ruang, dimana terdapat dua jenis aktivitas, yaitu aktivitas produksi dan wisata (rekreatif - edukatif). Untuk menunjang aktivitas, maka konsep fasilitas pada dasarnya untuk menunjang aktivitas yang telah direncanakan, yang secara umum terbagi atas fasilitas produksi dan wisata.

\section{Sintesis}

Berdasarkan hasil analisis dan pengembangan konsep, maka dikembangkan rencana blok (blockplan) yang kemudian menjadi acuan pengembangan rencana tapak (Gambar 7).

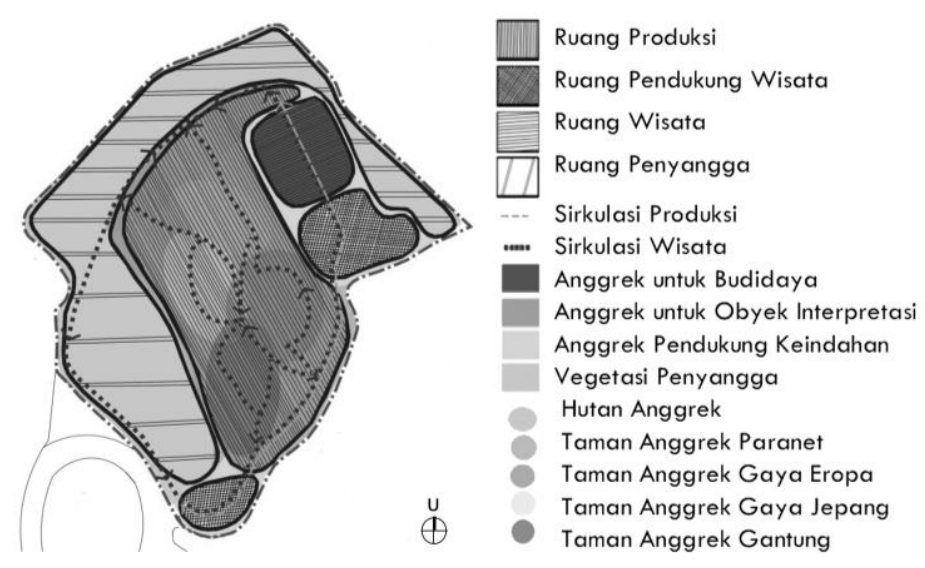

Gambar 7. Rencana Blok

Sumber: Hasil Sintesis, 2013 


\section{Perencanaan}

Pada tahap ini block plan dituangkan menjadi rencana tapak (Gambar 8) melalui deliniasi ruang, pengisian ruang dengan elemen tapak baik elemen lunak (softscape) maupun keras (hardscape), serta perencanaan karakter ruang melalui bentuk elemen tapak dan arahan elemen desainnya. Rencana tapak yang dihasilkan disertai ilustrasi sebagai gambaran visual situasi tapak yang diharapkan (Gambar 9).

Ruang yang dihasilkan menjabarkan konsep ruang yang terbagi menjadi lima ruang (Tabel 1). Kelima ruang tersebut adalah: (1) ruang penerimaan sebagai akses pengunjung dan pintu utama, serta menampilkan identitas kebun anggrek untuk menarik pengunjung; (2) ruang pelayanan wisata, yang memanfaatkan bangunan pengelola dan sebagian rumah kaca, menyediakan berbagai fasilitas penunjang seperti ruang informasi, ruang multimedia dan workshop, kios suvenir, perpustakaan, musholla, kantin, dan toilet; (3) ruang wisata utama yang menampilkan wisata edukatif anggrek dalam bentuk rumah kaca, taman anggrek dan hutan anggrek; (4) ruang produksi sebagai tempat budidaya anggrek dari proses pembibitan sampai pembungaan pada dua buah rumah kaca eksisting; serta (5) ruang penyangga untuk melindungi tapak dari gangguan luar (buffer) sekaligus melindungi sumberdaya lahan dari erosi tanah.

Tabel 1. Rencana Luasan Ruang

\begin{tabular}{clcc}
\hline No. & \multicolumn{1}{c}{ Ruang } & Luas $\left(\mathbf{m}^{2}\right)$ & $\begin{array}{c}\text { Persentase } \\
(\mathbf{\%})\end{array}$ \\
\hline 1 & Penerimaan & 250 & 2,9 \\
\hline 2 & Pelayanan & 603 & 7,2 \\
\hline 3 & Wisata utama & 3.770 & 44,6 \\
\hline 4 & Produksi & 585,5 & 6,9 \\
\hline 5 & Penyangga & 3.251 & 38,4 \\
\hline
\end{tabular}

Sumber: Hasil Perencanaan, 2013

Sebagai pengikat antar ruang, sirkulasi secara garis besar terdiri atas sirkulasi produksi dan wisata. Sirkulasi produksi selebar $4 \mathrm{~m}$ merupakan jalur pengelolaan dan produksi anggrek untuk lintasan alat-alat pertanian dan pengangkutan hasil yang direncanakan menyatu dengan jalur pejalan kaki dengan pertimbangan efisiensi luasan tapak. Selain itu tedapat pula jalur sirkulasi produksi di sekitar rumah kaca yang direncanakan selebar $1,7 \mathrm{~m}$. Sirkulasi wisata berupa jalur yang menghubungkan ruang-ruang wisata (1-2 m), yang mencakup jalur di dalam rumah kaca untuk wisata edukasi, jalur di dalam paranet untuk interpretasi, serta sikulasi diluar bangunan yang digunakan untuk mengakses atraksi wisata dalam kebun anggrek.

Vegetasi yang dikembangkan, yaitu utama dan pendukung. Vegetasi utama di tapak yaitu anggrek, penempatannya mempertimbangkan habitasi anggrek serta lingkungan tumbuhnya (Tabel 2). Anggrek dapat tumbuh di atas tanah (terestrial), di batuan (litofit), di atas serasah (saprofit), dan yang menempel di batang pohon (epifit) (Darmono, 2004). Untuk tumbuh optimal, tanaman anggrek membutuhkan persyaratan khusus terkait kebutuhan cahaya, suhu dan kelembapan (Anggara, 2008). Oleh karenanya di luar rumah kaca habitasi anggrek akan dilindungi struktur paranet sebagai perlakuan untuk mendapatkan kondisi lingkungan tumbuh optimal. Selain itu, terdapat vegetasi penyangga untuk mempertahankan kondisi fisik tapak sekaligus mengamankan tapak dari gangguan luar (buffer), berupa pohon jati dan bambu yang merupakan vegetasi eksisting. Sedangkan tanaman penyangga untuk kestabilan lereng berupa vegetasi penahan erosi kombinasi antara semak dan penutup tanah yaitu semak kaliandra (Calliandra calothyrsus) dan lamtoro (Leucaena leucocephala) ditanam tidak rapat, serta penutup tanah sirih belanda (Scindapsus sp) untuk menekan erosi percikan (splash erosion). 
Tabel 2. Rencana Vegetasi Utama

\begin{tabular}{|c|c|c|c|}
\hline Tujuan & Lokasi & Golongan & Genus \\
\hline $\begin{array}{l}\text { Budidaya } \\
\text { dan ekonomi }\end{array}$ & Ruang produksi (rumah kaca) & Anggrek spesies & Phalaenopsis \\
\hline \multirow{12}{*}{$\begin{array}{l}\text { Obyek interpretasi } \\
\text { (edukasi) }\end{array}$} & Ruang wisata utama (hutan) & $\begin{array}{l}\text { Anggrek spesies } \\
\text { (epifit) }\end{array}$ & Dendrobium \\
\hline & \multirow{6}{*}{ Ruang wisata utama (paranet) } & \multirow{4}{*}{$\begin{array}{l}\text { Anggrek spesies } \\
\text { (epifit \& saprofit) }\end{array}$} & Phalaenopsis \\
\hline & & & Oncidium \\
\hline & & & Dendrobium \\
\hline & & & Cattleya \\
\hline & & \multirow{2}{*}{$\begin{array}{l}\text { Anggrek hybrid } \\
\text { (epifit \& saprofit) }\end{array}$} & $\begin{array}{l}\text { Doritaenopsis } \\
\text { Aranda }\end{array}$ \\
\hline & & & Brassolaeliocattleya \\
\hline & $\begin{array}{l}\text { Ruang wisata utama (taman anggrek } \\
\text { gantung) }\end{array}$ & Anggrek epifit & Dendrobium \\
\hline & \multirow{2}{*}{$\begin{array}{l}\text { Ruang wisata utama (taman } \\
\text { anggrek gaya Eropa) }\end{array}$} & \multirow{2}{*}{ Anggrek epifit } & Dendrobium \\
\hline & & & Oncidium \\
\hline & \multirow{2}{*}{$\begin{array}{l}\text { Ruang wisata utama (taman } \\
\text { anggrek gaya Jepang) }\end{array}$} & \multirow{2}{*}{ Anggrek litofit } & Dendrobium \\
\hline & & & Phalaenopsis \\
\hline \multirow{4}{*}{ Estetis } & \multirow{4}{*}{$\begin{array}{l}\text { Ruang pendukung wisata dan ruang } \\
\text { produksi (sekitar rumah kaca) }\end{array}$} & \multirow{2}{*}{ Anggrek spesies } & Vanda \\
\hline & & & Renanthera \\
\hline & & \multirow{2}{*}{ Anggrek hybrid } & Mokara \\
\hline & & & Ascocenda \\
\hline
\end{tabular}

Sumber: Hasil Perencanaan, 2013

Rencana aktivitas wisata aktivitas berdasarkan ruang yang dibentuk dimana akan ditunjang dengan fasilitas untuk kemudahan, kenyamanan, dan keamanan pengunjung (Tabel 3). Aktivitas yang dikembangkan mempertimbangkan kebutuhan masyarakat terhadap kontak dengan elemen alam dan interaksi manusia (Matsuoka dan Kaplan, 2008), yang diwujudkan dalam bentuk mengenal bunga anggrek, menikmati estetika berbagai jenis anggrek, berekreasi di taman-taman tematik, serta berinteraksi sosial melalui aktivitas kolektif yang diorganisir pengelola kebun. Perpaduan antara keragaman anggrek, berbagai aktivitas edukatif-rekreatif, dan penataan elemen taman yang estetis diharapkan dapat memberikan pengalaman bagi pengunjung serta sebagai elemen yang memenuhi preferensi pengunjung dalam berekreasi sebagaimana dikemukakan oleh Polat dan Akay ( 2015) dalam hasil penelitiannya.

Meskipun kelerengan merupakan pembatas penggunaan ruang, namun tidak menjadi halangan untuk menciptakan berbagai daya tarik wisata dalam tapak sebagaimana tercermin dari rencana tapak dan aktivitas. Kondisi iklim yang kurang sesuai untuk pembungaan anggrek pun diatasi dengan pengadaan paranet yang membantu menekan intensitas panas matahari. Beragam taman anggrek seperti orchid jungle, taman anggrek gantung, rumah anggrek, taman anggrek gaya Jepang dan Eropa yang ditempatkan di area berlereng sebelah selatan tapak, merupakan obyek yang menarik bagi pengunjung. Namun demikian, dengan kondisi fisik lereng yang merupakan faktor penentu kapasitas tapak, maka pengelolaan melalui pembatasan jumlah pengunjung dalam satuan waktu perlu diperhitungkan. Adapun daya dukung tapak dalam menampung pengunjung disajikan pada Tabel 4.

Tabel 3. Rencana Aktivitas Dan Fasilitas Wisata

\begin{tabular}{llll}
\hline Ruang & Sub Ruang & \multicolumn{1}{c}{ Aktivitas } & \multicolumn{1}{c}{ Fasilitas } \\
\hline \multirow{2}{*}{ Penerimaan } & Membeli tiket & Loket tiket \\
\cline { 2 - 3 } & & Memperoleh informasi tata letak ruang & Signage main entrance, \\
\hline
\end{tabular}




\begin{tabular}{|c|c|c|c|}
\hline Ruang & Sub Ruang & Aktivitas & Fasilitas \\
\hline \multirow{4}{*}{$\begin{array}{l}\text { Pendukung } \\
\text { wisata }\end{array}$} & & dan fasilitas & Signage peta \\
\hline & \multirow{3}{*}{ Pelayanan } & $\begin{array}{l}\text { Memperoleh informasi lengkap mengenai } \\
\text { obyek dan atraksi dalam Kebun Anggrek }\end{array}$ & $\begin{array}{l}\text { Front desk, perpustakaan, } \\
\text { booklet, peta }\end{array}$ \\
\hline & & $\begin{array}{l}\text { Belanja cinderamata khas Kebun } \\
\text { Anggrek TKL }\end{array}$ & $\begin{array}{l}\text { Souvenir corner, book } \\
\text { store }\end{array}$ \\
\hline & & Makan dan duduk-duduk, istirahat & $\begin{array}{l}\text { Kantin, tempat sampah, } \\
\text { toilet, musholla }\end{array}$ \\
\hline \multirow{4}{*}{$\begin{array}{l}\text { Wisata } \\
\text { utama }\end{array}$} & $\begin{array}{l}\text { Kreasi Anggrek } \\
\text { (Wisata } \\
\text { budidaya, hobi, } \\
\text { terapi) }\end{array}$ & $\begin{array}{l}\text { Mengamati demo kegiatan budidaya, } \\
\text { melihat pameran/display, mengikuti } \\
\text { workshop budidaya atau berkreasi de- } \\
\text { ngan anggrek (merangkai, melukis, dsb) }\end{array}$ & $\begin{array}{l}\text { Rumah kaca, mezanin } \\
\text { display, multimedia room, } \\
\text { ruang workshop }\end{array}$ \\
\hline & $\begin{array}{l}\text { Orchid theme } \\
\text { gardens (Taman } \\
\text { aggrek tematik) }\end{array}$ & $\begin{array}{l}\text { Menelusuri dan mengobservasi anggrek } \\
\text { di taman-taman tematik (taman gantung, } \\
\text { paranet, taman eropa, taman jepang), } \\
\text { duduk-duduk, sightseeing }\end{array}$ & $\begin{array}{l}\text { Papan interpretasi } \\
\text { Paranet, signage anggrek, } \\
\text { tempat sampah, bangku }\end{array}$ \\
\hline & $\begin{array}{l}\text { Orchid Jungle } \\
\text { (Hutan anggrek) }\end{array}$ & $\begin{array}{l}\text { Menelusuri dan mengobservasi anggrek } \\
\text { di hutan anggrek, duduk-duduk, } \\
\text { sightseeing }\end{array}$ & $\begin{array}{l}\text { Papan interpretasi, } \\
\text { signage orchid forest, } \\
\text { signage anggrek, tempat } \\
\text { sampah, bangku, dek }\end{array}$ \\
\hline & Orchid's outlet & $\begin{array}{l}\text { Belanja tanaman anggrek (bibit, bunga) } \\
\text { dan bahan-alat budidaya anggrek }\end{array}$ & Counter penjualan \\
\hline Produksi & & Pembibitan-pembungaan & Rumah kaca \\
\hline
\end{tabular}

Sumber: Hasil Perencanaan, 2013

Tabel 4. Daya Dukung Ruang

\begin{tabular}{llccc}
\hline No & \multicolumn{1}{c}{ Lokasi } & $\begin{array}{c}\text { Kapasitas (orang) } \\
\text { per satuan rotasi }\end{array}$ & $\begin{array}{c}\text { Jumlah rotasi } \\
\text { per hari }\end{array}$ & $\begin{array}{c}\text { Kapasitas per } \\
\text { hari (orang) }\end{array}$ \\
\hline 1 & R Informasi & $11 / 1$ jam & 7 & 77 \\
\hline 2 & R Multimedia & $10 / 1$ jam & 7 & 70 \\
\hline 3 & Kantin & $20 / 1,5$ jam & 5 & 100 \\
\hline 4 & Rumah kaca & $20 / 1$ jam & 7 & 140 \\
\hline 5 & Jalur Hutan Anggrek & $12 / 30$ menit & 14 & 168 \\
\hline 6 & Jalur Taman Anggrek Gantung & $11 / 30$ menit & 14 & 154 \\
\hline 7 & Jalur Taman Anggrek Paranet & $11 / 30$ menit & 14 & 154 \\
\hline 8 & Jalur Taman Gaya Eropa & $8 / 30$ menit & 14 & 112 \\
\hline 9 & Jalur Taman Gaya Jepang & $8 / 30$ menit & 14 & 112 \\
\hline
\end{tabular}

Sumber: Hasil Perencanaan, 2013

\section{Kesimpulan}

Kebun anggrek TKL memiliki potensi tapak yang dapat dikembangkan sebagai obyek wisata edukasi untuk meningkatkan jumlah pengunjung TKL. Ruang yang terbentuk untuk menunjang fungsi wisata edukasi di kebun anggrek ini meliputi ruang penerimaan, pelayanan, area kreasi anggrek, taman anggrek tematik, hutan anggrek, dan outlet anggrek.

Vegetasi di tapak, baik anggrek maupun non-anggrek, merupakan potensi yang dapat mendukung wisata edukasi dan perlindungan sumber daya fisik tanah dan air. Anggrek berpotensi sebagai obyek interpretasi, edukasi dan keindahan visual yang dapat dirancang sedemikian rupa dengan memunculkan anggrek sebagai tema utamanya untuk menarik pengunjung ke tapak. Berbagai genus anggrek akan ditampilkan baik di atas tanah, serasah, bebatuan, dan batang pohon. Sementara itu untuk upaya konservasi tapak pada bagian lereng akan ditanami semak dan rumput penahan erosi. 
Rencana tapak yang disusun pada dasarnya merupakan integrasi hasil analisis dan pengembangan konsep yang tertuang dalam rencana blok. Dalam rencana tapak terlihat bahwa penataan dan pemilihan elemen tidak semata-mata mengeksploitasi ruang untuk tujuan produksi dan wisata, namun juga mempertimbangkan kelestarian kondisi fisik tapak. Hal ini ditunjukkan melalui pembentukan ruang penyangga serta pemanfaatan ruang-ruang yang intensitasnya sesuai dengan kapasitas fisiknya.

\section{Daftar Pustaka}

Anggara, A. (2008). Merawat Anggrek. Jakarta: Penebar Swadaya.

Booth, K. (1983). Basic Elements for Landscape Architecture Design. Illionis: Waveland Press.

BPS Kota Magelang. (2019). Statistik Daerah Kota Magelang 2019. Magelang: BPS.

BPS Kota Magelang. (2018). Statistik Daerah Kota Magelang 2017. Magelang: BPS.

[CTC] Canadian Tourism Commission. (2004). Defining Tomorrow's Tourism Product Packaging Experiences- Research Report 2004-7. Ottawa: Canadian Tourism Commission.

Darmawijaya, M. I. (1990). Klasifikasi Tanah: Dasar Teori Bagi Peneliti Tanah dan Pelaksana Pertanian di Indonesia. Yogyakarta: Gadjah Mada University Press.

Darmono, D. W. (2004). Permasalahan Anggrek dan Solusinya. Jakarta: Penebar Swadaya.

Gunn, C. A. (1997). Vacationscape: Developing Tourist Areas. Washington: Taylor and Francis.

Iswanto, H. (2002). Petunjuk Perawatan Anggrek. Jakarta: Agromedia Pustaka

Matsuoko, R.H. dan R. Kaplan. (2008). People needs in the urban landscape: Analysis of Landscape and Urban Planning contributions. Landscape and Urban Planning Journal 84, 7-19. doi:10.1016/j.landurbplan.2007.09.009

Novaria, A. (2018). Devisa dari Pariwisata Terus meningkat. Retrieved from http://mediaindonesia.com
Nurisjah, S. dan Q. Pramukanto. (2007). Perencanaan Lanskap (Penuntun Praktikum). PS Arsitektur Lanskap Jur. Budidaya Pertanian Faperta IPB.

Otto J.E. dan Ritchie, J.R.B. (1996). The Service Experience in Tourism. Tourism Management 17(3), 165-174.

Pemkot Magelang (2019). Kondisi Geografis. Retrieve from http://www.magelangkota.go.id/

Polat A.T. dan A. Akay (2015). Relationships between the visual preferences of urban recreation areausers and various landscape design elements. Urban Forestry \& Urban Greening 14, 573-582

Ritchie, B. W., Neil C, \& Christopher PC. (2003). Managing Educational Tourism. England: Channel View Clevedon Publication.

Simonds, OJ dan BW. Starke. (2006). Landscape Architecture. New Yortk: McGraw-Hill Book Company.

Spirn, AW. (1998). The Language of Landscape. US: Thomson-Shore Inc.

Wijayanti, A., J Damanik, C. Fandeli \& Sudarmadji. (2017). Analysis of Supply and Demand to Enhance Educational Tourism Experience in the Smart Park of Yogyakarta, Indonesia. Economies 5(42), doi:10.3390/ economies5040042

Yulia N.D. dan R.M. Yanti. (2010). Anggrek Epifit dan Pohon inangnya di Kawasan Gunung Penanggungan, Pasuruan-Jawa Timur. Jurnal Berk. Penel. Hayati, Edisi Khusus 4A: 37-40.

$\mathrm{Xu}$, J.B. (2010). Perceptions of tourism products. Tourism Management 31, 607-610. 